\title{
Strategy on The Effectiveness of Learning Outcomes of Manufacturing Calculus Using Edlink in The Covid-19 Pandemic
}

\author{
Wahyuningsih ${ }^{1^{*}}$, Adi Jufriansah ${ }^{2}$, Agnesia Bergita Anomeisa ${ }^{3}$, Kartini \\ Rahmanisa ${ }^{4}$
}

${ }^{1}$ IKIP Muhammadiyah Maumere, Departement of Mathematic Education

2IKIP Muhammadiyah Maumere, Lembaga Sistem Informasi dan Teknologi Pembelajaran

${ }^{3}$ IKIP Muhammadiyah Maumere, Lembaga Penjaminan Mutu

${ }^{4}$ IKIP Muhammadiyah Maumere, Lembaga Penilaian Pengembangan Kurikulum dan Pembelajaran

*Corresponding author: Maumere, Nusa Tenggara Timur, 86118, Indonesia. e-mail addresses: wahyuningsih.ikipmu@gmail.com

\section{Article in fo \\ How to cite this article: \\ Wahyuningsih, Jufriansah, A., Anomeisa, AB., Rahmanisa, K. (2021). Strategy on The Effectiveness of Learning Outcomes of Manufacturing Calculus Using Edlink in The Covid-19 Pandemic. Eduma: Mathematics Education Learning And Teaching, 10(1), 39 - 48. doi:http://dx.doi.org/10.24235/eduma.v8i2.8066}

Article history:

Received: 03 05, 2021

Accepted: 05 26, 2021

Published: 07, 2021

Copyright (C) 2021

EduMa: Mathematics Education Learning and Teaching under the Creative Commons Attribution 4.0 International License.

\begin{abstract}
The Covid-19 pandemic in Indonesia resulted in changes to the learning implementation system at IKIP Muhammadiyah which was carried out face-to-face. The presence of the EdLink platform in the learning system at IKIP Muhammadiyah can be a solution by providing easy online learning offers for lecturers and students. This study aims to analyze the effectiveness of learning achievement strategies during the pandemic in calculus subject variables using the EdLink platform. This study used qualitative descriptive data, with the target of testing mathematics education students in semester 5 and semester 7 with 29 students. The instruments used in this study were a questionnaire on the effectiveness of learning outcomes, a student response questionnaire about the ability of lecturers to manage online learning, and a student response questionnaire using EdLink. The results showed that the effective strategy of learning outcomes in the variable calculus course was widely applied effectively during the Covid-19 pandemic.
\end{abstract}

K e y w o r d s :

Covid-19 Pandemic; Learning Management System; Edlink Application; Qualitative Descriptive Data; Mathematics Education 


\section{INTRODUCTION}

Oey-Gardiner et al. (2017) states that disruptive change demands a change in teaching methods that have changed from being centered on lecturers to being centered on students. Thus, students also need to be active in learning to achieve the goals of higher education. The COVID-19 pandemic has plagued various countries. Including in Indonesia, until now, it is still increasing. It has resulted in several sectors taking advantage of online applications, including in the education sector. The use of online applications in various sectors is also part of the demands of the era of disruption in the industrial revolution 4.0 (Handayani, 2020). We continue to strive to innovate the use of online applications in the education sector to support learning effectiveness. Mustofa (2019) and Mulyana (2020) explain that, with technology development, teaching and learning methods can cross the physical boundaries of lecture halls, campuses, and even the state. If this is not resolved immediately, the learning process in higher education cannot run.

Ally (2011) mentions several advantages of online learning, for students, timezone, location, and distance are not a problem in online learning. In online learning, students can access online material at any time, while offline learning requires matching study time between students and teachers (Dixson, 2015). Students can use the internet to access the latest relevant learning materials and communicate with experts in the fields following the ongoing learning material. The application of knowledge and skills in specific contexts is facilitated in online learning because students can obtain teaching materials/materials, complete assignments or quizzes in online classes while working or in their own space, and contextualize learning. As for teachers, learning activities can take place indefinitely by time and place. Online learning can make it easier for teachers to update the material, and students can see changes quickly. When students can access material on the internet, it is easier for teachers to direct them to appropriate information based on their needs (Alisa \& Lisvita, 2020).

Sobri (2020) states that there are five principles in implementing online learning in tertiary institutions. The principles are: (1) the relevance of learning design and student learning; (2) online learning delivery must be effective; (3) adequate support from faculty and teaching staff to students; (4) quality participation to increase the breadth and depth of student learning, and (5) contingency plans to deal with unexpected incidents of applications used in learning. It is reinforced by Mishra, et al. (2020), García-Peñalvo et al. (2020), and Ali, (2020), one application that can be used to facilitate learning is (Sentra Vidya Utama) SEVIMA EdLink. EdLink is a product from SEVIMA that specifically manages lectures as efficiently as playing social media and makes the lecture process more effective. A lecture schedule notification can create class groups integrated with Siakad (Sistem informasi akademik or Academic information system )and make attendance with a smartphone. EdLink has recently become a popular social media in several universities in general, and IKIP Muhammadiyah uses Edlink as a medium for students and lecturers to meet face to face online. Edlink users, according to data, are approximately 150,000 students, 7000 lecturers, 270 campuses, and ten partners in the world of education.

EdLink is a popular technology that can use as a learning tool (Novandini \& Luta, 2018). EdLink presents an application feature that can build a fun lesson related to the teacher's various discussion topics (Rosanti, et al., 2020). EdLink is a type of Instant Messaging 
technology such as SMS assisted by internet data with more attractive supporting features, including a timeline with various menus. Based on this, the EdLink application is useful as a learning tool in the digital era. Learning in tertiary institutions is one of the objects of the thriving use of the EdLink application (Marlina, 2020).

Some researchers who have implemented EdLink in learning have concluded that problem-based online learning (PBOL) assisted by Edlink can improve learning outcomes and be more efficient to use (Fitriyani, 2020). Another opinion states that Edlink is a valuable application in mobile-based learning to support the blended learning strategy (Wahyuningtyas, et al., 2020; Darma, et al., 2020). However, these studies are limited to Edlink as a medium in learning and support blended learning. Based on this description, this study aims to analyze the strategy for the effectiveness of learning achievement during the pandemic in the variable calculus course using the Edlink platform.

\section{METHODS}

The research method uses qualitative descriptive data. The research target was 29 students in the mathematics education study program, consisting of semester 5 and semester 7 in the odd 2020-1 period. The curriculum that includes these courses uses KKNI 4.0, which synergizes with the demands of the 21 st century today. The complete research diagram is presented in Figure 1.

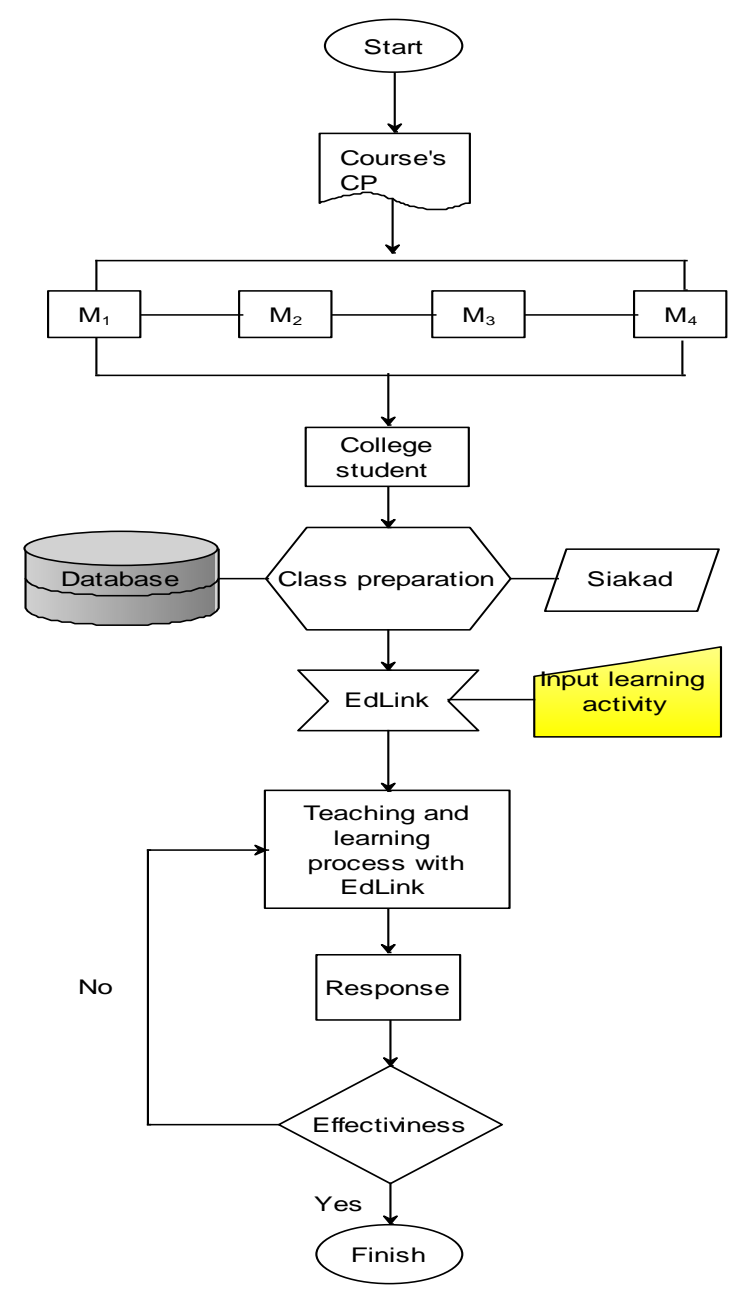

Figure 1

Research flow diagram 
The instruments in this study were in the form of a learning outcome effectiveness questionnaire, a learning implementation questionnaire, and a student response questionnaire as a user. Retrieval of research data was carried out by giving questionnaires to students after going through lecture meetings 14 times. The data processing used is descriptive qualitative which refers to data reduction, data presentation, and conclusions.

Table 1

The criteria for the effectiveness of learning outcomes

\begin{tabular}{ll}
\hline Percentage (\%) & Criteria \\
\hline $90-100$ & Very Effective \\
$80-89$ & Effective \\
$60-79$ & Effective enough \\
$\leq 60$ & Ineffective \\
\hline
\end{tabular}

Table 2

Learning implementation criteria

\begin{tabular}{ll}
\hline Percentage (\%) & Criteria \\
\hline$p \geq 100$ & Very good \\
$80 \leq p<90$ & Good \\
$70 \leq p<80$ & Sufficient \\
$60 \leq p<70$ & Deficient \\
$p \leq 60$ & Not good \\
\hline
\end{tabular}

Table 3

The criteria for the effectiveness of student responses as users

\begin{tabular}{ll}
\hline Range of values & Criteria \\
\hline $3,25<X=4$ & Very Effective \\
$2,5<X=3,25$ & Effective \\
$1,75<X=2,5$ & Effective enough \\
$1<X=1,75$ & Ineffective \\
\hline
\end{tabular}

\section{RESULT AND DISCUSSION}

The FGD (Focus Group Discussion) was conducted to obtain an effective strategy that met several aspects of the requirements, namely, learning outcomes following the KKNI 4.0 national curriculum standard regarding the most optimal process in supporting online learning. In this phase, several experts share expertise through scientific discussions to find lessons that match learning outcomes. These experts are curriculum experts, learning strategists, learning evaluation experts, and lecturers who teach courses. It is by research conducted by Kawuri et al. (2019). This phase's output is the design of learning outcomes, including online learning from several meetings and online class readiness. Table 4 is the RPS learning outcomes design that will be applying online over an odd number of 2020-1 period in multi-variable calculus courses. 
Table 4

Design of Learning Outcomes

M1 Be able to explain multiple variable functions, including vector-valued functions, derivatives (partial, total, directed, gradient), algebra of functions, the composition of parts and their products, high-order derivatives, Taylor theorem, extreme conditional problems, and paths.

M2 Able to examine the definition of the multi-variable function to determine the derivative of the operation.

M3 Able to analyze the derivative of the variable function of more than two variables.

M4 Able to apply multivariable derivative functions to contextual problems.

The RPS contains learning outcomes, which are then validated using an expert assessment approach. Expert assessments are carried out by learning strategy experts, namely the Quality Assurance Institute (LPM) and the Learning Curriculum Assessment and Development Institute (LPPKP) IKIP Muhammadiyah. Relevant problems in learning encourage student involvement to solve issues in multi-variable calculus courses by utilizing appropriate technology during a pandemic. It is under the research conducted by Dwi et al. (2020). EdLink implementation was carried out for one semester, as shown in Figure 2.

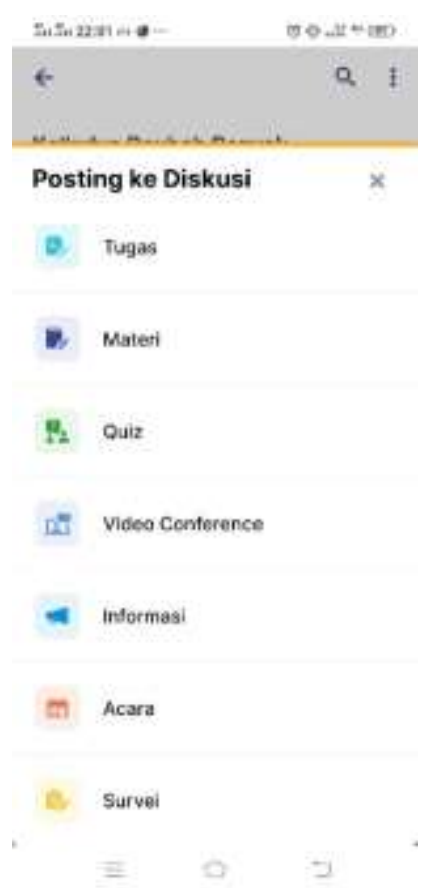

(a)

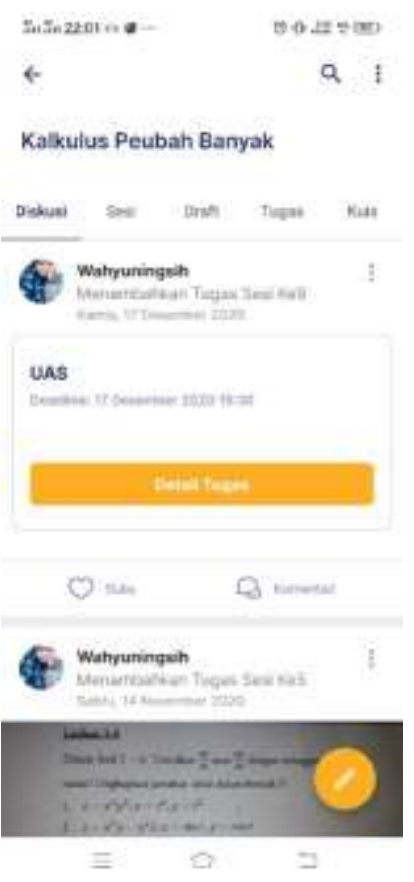

(b)

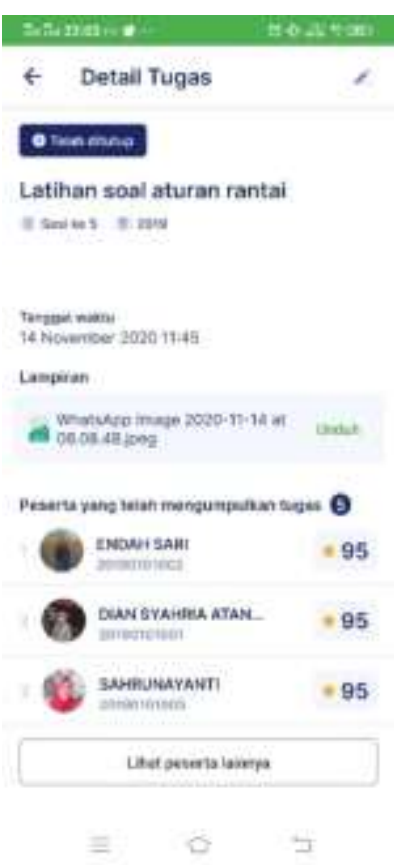

(c) 


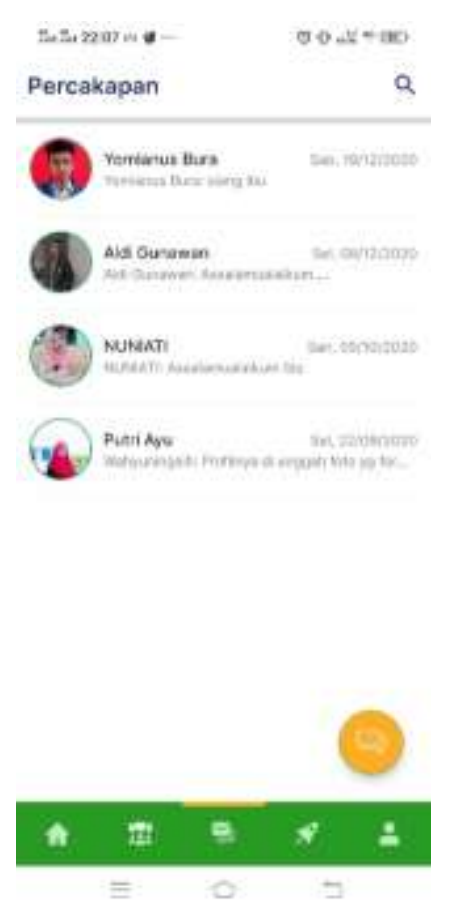

(d)
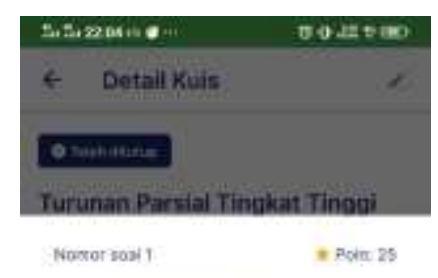

Perhatikan fungsi pada gambar tersebut dan tentukan nilai dari fungsi tersebut.

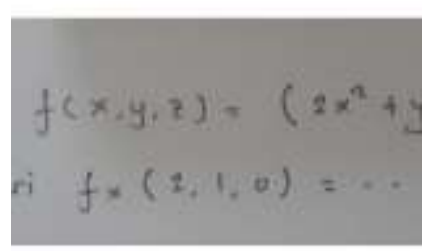

2700

$\times 243$

$\times 81$

(e)

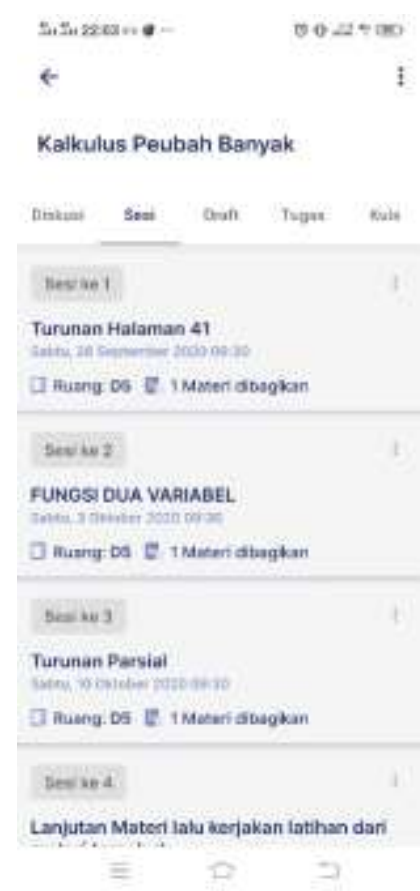

(f)

Figure 2

Dashboard of learning activities using Edlink; (a) Learning activity interface, (b)

Discussion dashboard, (c) task dashboard, (d) conversation dashboard, (e) quiz dashboard, (b) lecture session dashboard

Marbun (2020) states a comprehensive activity design strategy, provides integrative opportunities for students, asks questions during online learning sessions, and the suitability of browsing information used by students to fit the product to be achieved. It is in line with this research shown in Figure 3.

Figure 3 shows the percentage of learning outcomes by students after using EdLink. Based on the percentage number, it has been demonstrated that the learning outcomes during the 2020-1 odd semester period are effective

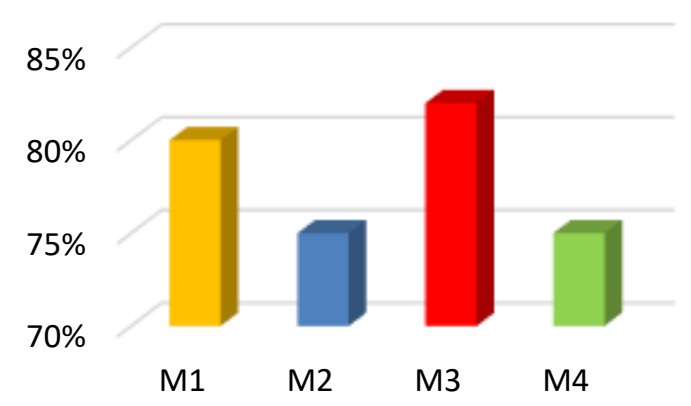

Figure 3

Percentage of the effectiveness of learning outcomes

Learning assessment using the Edlink by students is shown in Figure 4. Figure 4 shows the learning assessment questionnaire results using the Edlink by students to the lecturer at the end of the meeting. Overall, each total score obtained exceeds the value of 72 , and the result is that learning using EdLink is useful during a pandemic. 
In addition to the assessment of learning by lecturers, other aspects studied included usability, ease of use of applications, ease of learning, and satisfaction. In the usability aspect, all students stated that learning using Edlink has sufficient benefits. Students note that even though the learning process is limited in the virtual world, the learning syntax can be conveyed well through the features provided.

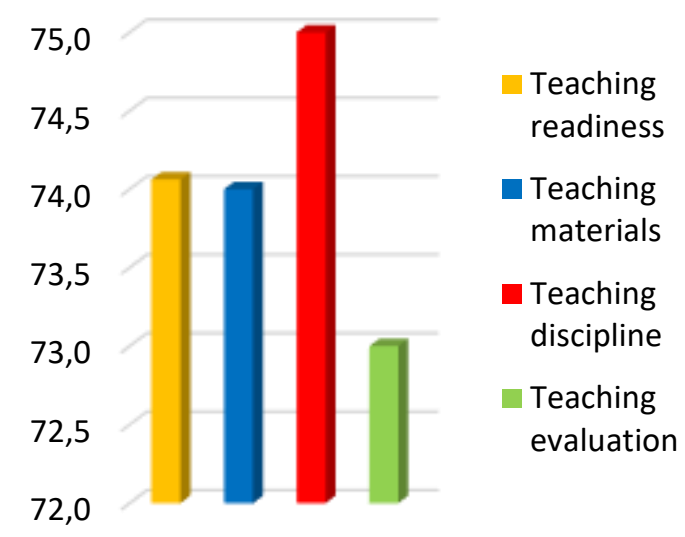

Figure 4

Learning assessment using EdLink by students to lecturers

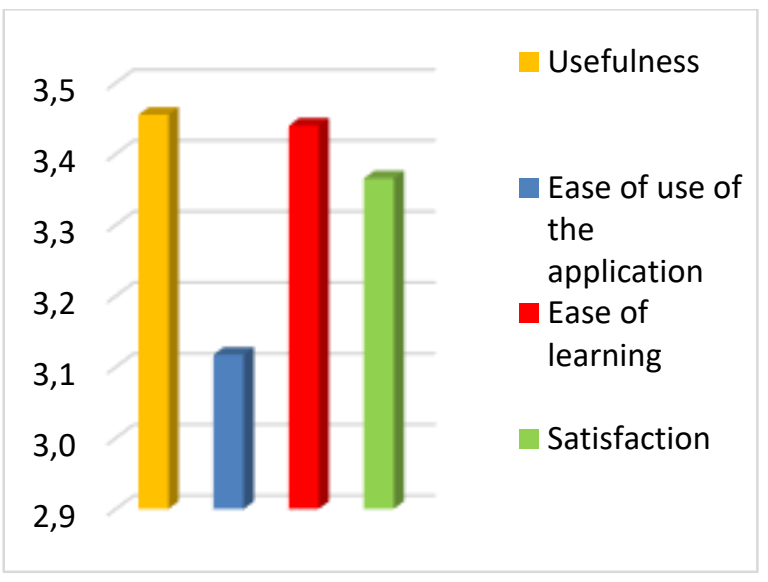

Figure 5

Student responses as EdLink users

Several students who took the variable calculus class stated that it was easy to use applications such as uploading assignments, answering quizzes, and taking conferences. Students have no difficulty with the interface provided in learning by lecturers who deliver courses regarding the ease of learning aspects. In discussions, students also feel free to express opinions. The lecturer who teaches does not dominate in facilitating virtual conversations, but how to create comfortable conditions so that learning is dynamic and fun even though it is limited to the world of the internet. As for the satisfaction aspect, students stated that the application used was exciting and provided information about many variable calculus courses.

Based on the results of effective questionnaires and interviews, the EdLink application is effective and has a high potential for learning during a pandemic. Figure 5 shows the results of student responses after using Edlink.

Figure 5. Obtained from the results of the questionnaire by students at the end of the meeting. Received a total mean score of 3.3 from a maximum score of 4 with the category of use 3.5, ease of use of applications 3.1, the comfort of learning 3.4, and satisfaction 3.4. 
It indicates that the response given by students is excellent. Meanwhile, the interviews with interviews showed that students helped use the EdLink in the multi-variable calculus course.

\section{CONCLUSION AND IMPLICATION}

\section{Conclusion}

The FGD (Focus Group Discussion) has produced an output in a learning outcome design that includes online learning from several meetings and online class readiness. A comprehensive activity design strategy, providing integrative opportunities for students. The results of student learning outcomes and the assessment questionnaire results show that EdLink was effectively applied during the Covid-19 pandemic.

Students are enthusiastic about participating in multi-variable calculus classes based on the results of useful questionnaires and interviews. It is found that the EdLink application is effective and has a high potential for use in learning during a pandemic. It is shown from the results of the questionnaire by students at the end of the meeting. The total average score is 3.3 from the maximum score of 4 .

\section{Implication}

This research is limited to the CP multi-variable calculus course. Furthermore, analysis will be carried out at the study program level by analyzing each subject using EdLink.

\section{Disclosure statement}

The authors reported no potential conflict of interest.

\section{ACKNOWLEDGMENTS}

The researcher expressed his gratitude to Lembaga Penelitian Pengembangan dan Pengabdian Masyarakat (LP3M) IKIP Muhammadiyah Maumere for research funding with OBE (Outcome Based Education) scheme.

\section{REFERENCES}

Aisa, A., \& Lisvita, L. (2020). Penggunaan Teknologi Informasi Dalam Pembelajaran Online Masa Covid-19. JoEMS (Journal of Education and Management Studies), 3(4), 47-52.

Ali, W. (2020). Online and remote learning in higher education institutes: A necessity in light of COVID-19 pandemic. Higher Education Studies, 10(3), 16-25. https://doi.org/10.5539/hes.v10n3p16

Bao, W. (2020). COVID-19 and online teaching in higher education: A case study of Peking University. Human Behavior and Emerging Technologies, 2(2), 113-115. https://doi.org/10.1002/hbe2.191

Darma, I. K., Karma, I. G. M., \& Santiana, I. M. A. (2020, February). Blended Learning, Inovasi Strategi Pembelajaran Matematika di Era Revolusi Industri 4.0 Bagi Pendidikan Tinggi. In PRISMA, Prosiding Seminar Nasional Matematika, 3, 527 539).

Dixson, M. D. (2015). Measuring student engagement in the online course: The Online Student Engagement scale (OSE). Online Learning, 19(4), n4. https://doi.org/10.24059/olj.v19i4.561 
Sulisworo, D., Rohmadheny, P. S., Fatimah, N., Arif, D. B., \& Saifuddin, M.F. (2020). Learning analytics to predict student achievement in online learning during Covid19 mitigation. International Journal of Psychosocial Rehabilitation, 24(10), 18441861.

Fitriani, Y. (2020). Analisa Pemanfaatan Learning Management System (Lms) Sebagai Media Pembelajaran Online Selama Pandemi Covid-19. Journal of Information System, Informatics and Computing, 4(2), 1-8. https://doi.org/10.52362/jisicom.v4i2.312

García-Peñalvo, F. J., Corell, A., Abella-García, V., \& Grande, M. (2020). Online assessment in higher education in the time of COVID-19. Education in the Knowledge Society, 21. https://doi.org/10.14201/eks.23013

Handayani, N. N. L. (2020). Pendidikan Perguruan Tinggi Era 4.0 Dalam Pandemi Covid19 Menuju Cyber University. PINTU: Jurnal Penjaminan Mutu, 1(2).

Kawuri, M. Y. R. T., Jufriansyah, A., Setiamukti, D. D., \& Sulisworo, D. (2019). Implementation E-Learning based moodle on physics learning in senior high school. Indonesian Journal of Science and Education, 3(2), 93-102. https://doi.org/10.31002/ijose.v3i2.1178

Marbun, P. (2020). Disain pembelajaran online pada era dan pasca covid-19. CSRID (Computer Science Research and Its Development Journal), 12(2), 129-142. https://doi.org/10.22303/csrid.12.2.2020.129-142

Marlina, E. (2020). Pengembangan Model Pembelajaran Blended Learning Berbantuan Aplikasi Sevima Edlink. Jurnal Padegogik, 3(2), 104-110. https://doi.org/10.22303/csrid.12.2.2020.129-142

Mishra, L., Gupta, T., \& Shree, A. (2020). Online teaching-learning in higher education during lockdown period of COVID-19 pandemic. International Journal of Educational Research Open, 1, 100012. https://doi.org/10.1016/j.ijedro.2020.100012

Mulyana, M., Rainanto, B. H., Astrini, D., \& Puspitasari, R. (2020). Persepsi Mahasiswa Atas Penggunaan Aplikasi Perkuliahan Daring Saat Wabah Covid-19. JAS-PT (Jurnal Analisis Sistem Pendidikan Tinggi Indonesia), 4(1), 47-56. OI: https://doi.org/10.36339/jaspt.v4i1.301

Mustofa, M. I., Chodzirin, M., Sayekti, L., \& Fauzan, R. (2019). Formulasi model perkuliahan daring sebagai upaya menekan disparitas kualitas perguruan tinggi. Walisongo Journal of Information Technology, 1(2), 151-160. OI : http://dx.doi.org/10.21580/wjit.2019.1.2.4067

Novandini, C. D., \& Luta, M. W. (2018). Pemanfaatan Kelas Virtual Sevima Edlink Untuk Memotivasi Mahasiswa Pendidikan Matematika Semester 1 Matakuliah Aljabar \& Trigonometri. In Prosiding Seminar Nasional Pendidikan Matematika Etnomatnesia.

Oey, M., Rahayu, S. I., Amin, M., Effendi, S., Darma, Y., Dartanto, T., \& Aruan, C. D. (2017). Era disrupsi peluang dan tantangan pendidikan tinggi Indonesia. Akademi Ilmu Pengetahuan Indonesia.

Rosanti, A., Alifiani, A., \& Nursit, I. (2020). Kemampuan Berpikir Kritis Matematis Menggunakan Model Pembelajaran E-Learning Berbantuan Aplikasi Sevima Edlink. Jurnal Penelitian, Pendidikan, dan Pembelajaran, 15(33).

Shahroom, A. A., \& Hussin, N. (2018). Industrial revolution 4.0 and education. International Journal of Academic Research in Business and Social Sciences, 8(9), 314-319. http://dx.doi.org/10.6007/IJARBSS/V8-I9/4593 
Sobri, M., Nursaptini, N., \& Novitasari, S. (2020). Mewujudkan kemandirian belajar melalui pembelajaran berbasis daring diperguruan tinggi pada era industri 4.0. Jurnal Pendidikan Glasser, 4(1), 64-71. https://doi.org/10.32529/glasser.v4i1.373

Wahyuningtyas, N., Zainul, R., Adri, M., Wedi, A., Surahman, E., Aisyah, E. N., ... \& Adnan, E. (2020, July). Development of Moodle-based Content Learning System in MKDK Student Development Subjects at LPTK in Indonesia. Journal of Physics: Conference Series, 1594(1), 012021. http://dx.doi.org/10.1088/1742$\underline{6596 / 1594 / 1 / 012021}$ 